\title{
Ruch niepodległościowy w Katalonii i jego znaczenie dla Katalończyków w drugiej dekadzie XXI wieku
}

\begin{abstract}
Abstrakt
W artykule podjęto problematykę ruchu niepodległościowego w Katalonii w drugiej dekadzie XXI wieku. Celem artykułu jest ukazanie ewolucji dążeń separatystycznych Katalonii w tamtym czasie w wymiarze politycznym oraz społecznym, i w konsekwencji stanowiska Katalończyków wobec tego zjawiska. Istotny element rozważań stanowi przedstawienie oraz analiza specyfiki i czynników wpływających na współczesny separatyzm kataloński, z uwzględnieniem kontekstu postrzegania Katalończyków jako narodu. Praca obejmuje także przedstawienie kształtującego się procesu niepodległościowego, w tym omówienie kluczowych wydarzeń, takich jak wyrok Trybunału Konstytucyjnego Hiszpanii z 2010 roku, tzw. referendum niepodległościowe w 2017 roku czy proces i wyrok katalońskich polityków z 2019 roku. Istotną częścią pracy jest ukazanie problematyki ruchu niepodległościowego w omawianym okresie w wymiarze społecznym, jego kształtującej się roli w społeczeństwie katalońskim oraz wpływu aktywności i działań samych Katalończyków na politykę i rozwój separatystycznych dążeń regionu.
\end{abstract}

Słowa kluczowe: Katalonia, kataloński ruch niepodległościowy, kataloński separatyzm, regionalizm, referendum 2017 


\begin{abstract}
Independence Movement in Catalonia and Its Significance for Catalans in the Second Decade of the $21^{\text {st }}$ Century

The paper focuses on the issues of the independence movement in Catalonia in the second decade of the $21^{\text {st }}$ century. The aim of this study is to explore the evolution of Catalonia's separatist aspirations in this period in terms of politics and especially society, and thus the position of Catalans towards this phenomenon. A significant element of the author's considerations is the demonstration and analysis of the specificity and factors determining contemporary Catalan separatism, as well as concerning the context of perceiving Catalans as a nation. The independence process in the second decade of the $21^{\text {st }}$ century, including treatment of events such as the judgment of the Spanish Constitutional Court in 2010, the independence referendum in 2017, or the trial and judgment of Catalan politicians in 2019, taken into account by the author, hold considerable importance for this work. The key part of the paper is to present the issues of the independence movement in the discussed period in terms of society; its emerging role in the Catalan society, and the impact of the activities and actions of Catalans themselves on the politics and development of the region's separatist aspirations.
\end{abstract}

Keywords: Catalonia, Catalan independence movement, Catalan separatism, regionalism, Referendum 2017

Druga dekada XXI wieku to okres o zasadniczym znaczeniu dla historii Katalonii i katalońskiego ruchu niepodległościowego. Wyrok Trybunału Konstytucyjnego Hiszpanii z 2010 roku okazał się punktem zapalnym w relacjach między rządem katalońskim i hiszpańskim, a także spowodował pogorszenie nastrojów społecznych. Trudno było bowiem przewidzieć, jak bardzo zaistniałe okoliczności wpłyną na dalszą sytuację Katalonii i rozwój jej separatystycznych dążeń. W ciągu kilku lat z punktu widzenia wielu Katalończyków pojawiła się jednak realna szansa na utworzenie własnej państwowości. W wymiarze politycznym i społecznym dokonało się w omawianym okresie wiele istotnych zmian, które wpłynęły na odrodzenie się ruchu niepodległościowego w regionie. W niniejszej pracy przedstawię i poddam analizie znaczące czynniki kształtujące proces dążenia Katalończyków do secesji. Dla rozważań ważne jest także uwzględnienie uwarunkowań katalońskiego regionalizmu i nacjonalizmu oraz związanego z tym 
kontekstu historycznego, co pozwala kompleksowo ująć oraz łatwiej zrozumieć istotę i specyfikę współczesnego ruchu niepodległościowego w regionie. Celem mojej pracy jest bowiem ukazanie ewolucji dążeń separatystycznych Katalonii w drugim dziesięcioleciu XXI wieku w wymiarze politycznym oraz społecznym, a w konsekwencji stanowiska Katalończyków wobec tego zjawiska. Artykuł w zdecydowanym stopniu ma charakter jakościowy i mieści się w podejściu neopozytywistycznym. W swoich rozważaniach skupię się na studium pojedynczego przypadku. Poprzez śledzenie procesu, jakim było kształtowanie się tendencji niepodległościowych w Katalonii w omawianym czasie, połączone z analizą źródeł pierwotnych i wtórnych będę poszukiwał korelacji i związków przyczynowo-skutkowych. Pozwoli to w odpowiedni sposób zbadać ewolucję, mechanizmy i rolę ruchu niepodległościowego w życiu politycznym i społecznym regionu katalońskiego w tamtym okresie.

\section{Postrzeganie Katalończyków jako narodu}

Opowiadając się za polityczną niezależnością regionu, kataloński ruch niepodległościowy opiera swoje postulaty na założeniu, że Katalończycy tworzą naród (Llibertat.cat, 2020). Źródła tej idei można doszukać się już w wieku XIX, kiedy to rozbudziła się katalońska świadomość narodowa, a nacjonalizm kataloński był szczególnie skoncentrowany na próbie utworzenia państwa, co znacznie wzmocniło tożsamość regionu (Toubeau, 2020: 11). Wpływ na rozwój tego zjawiska miał powstały w latach 30 . ruch odnowy narodowej zwany Renaixença, który skupiał się na odkrywaniu i badaniu katalońskiej historii, języka i kultury, jak również katalonizm (kat. catalanisme) ruch na rzecz obrony języka, historii i kultury katalońskiej, który wraz z powstawaniem takich ugrupowań, jak Lliga Regionalista czy Estat Català stopniowo zaczął nabierać znaczenia politycznego. Wyraźnym efektem działania ruchów pronarodowych i separatystycznych były dwie próby powołania niezależnego państwa katalońskiego - w 1931 roku przez Francesca Macià i w 1934 roku przez Lluísa Companysa i Jovera. 
Dziś samookreślenie się Katalończyków jako naród - w preambule do Statutu Autonomii z 2006 roku termin ów pojawia się jako odzwierciedlenie ,uczuć i woli mieszkańców Katalonii” (Ley Orgánica 6/2006) - uznawane jest za podstawę do żądania prawa do samostanowienia oraz obrony własnego języka, kultury czy instytucji. W Statucie znajdują się ponadto odniesienia do historii, wzmianki o wielowiekowej „stałej woli samorządności”, w takich instytucjach jak Generalitat ${ }^{1}$, oraz własnym systemie prawnym, co sprowadza się do twierdzenia, że prawa samorządu oparte są nie tylko na konstytucji państwa hiszpańskiego, ale także na prawach historycznych ludu katalońskiego.

Odnosząc się do samej definicji słowa „naród” pojawiającej się w literaturze, warto jednak wspomnieć, że w zależności od interpretacji ma ona różne znaczenia i wyodrębnia różne cechy zbiorowości. Wśród części badaczy istnieje bowiem przekonanie, że przynależność do narodu jest aktem woli jednostki w zależności od jej subiektywnych przekonań (Barwiński, 2004: 64). Według Montserrat Guibernau naród to grupa ludzka świadoma tworzenia wspólnoty, dzieląca wspólną kulturę, przywiązana do wyraźnie wyznaczonego terytorium, mająca wspólną przeszłość i plan na przyszłość oraz postulująca prawo „do rządzenia sobą” (to jest suwerenność narodu) (Guibernau, 2000: 989). Anthony David Smith wyróżnia takie cechy narodu, jak wspólne historyczne terytorium, mity i pamięć historyczna, kultura masowa, gospodarka oraz prawa i obowiązki jego członków (Smith, 1995: 57). Michael Hechter definiuje narody jako, grupy etniczne skoncentrowane terytorialnie" (Hechter, 2000: 14). Ernest Gellner postrzega naród głównie jako wspólnotę polityczną powstałą w wyniku idei nacjonalizmu jako postulatu pokrywania się jednostek politycznych z jednostkami etnicznymi (Gellner, 1983: 6-7). Jerzy Szacki zwraca natomiast uwagę na samo poczucie świadomości narodowej, czyli przynależności do wspólnoty definiowanej jako naród, która pojawia się nawet tam, gdzie brak jest ,wymienianych w «obiektywnych» definicjach

${ }^{1}$ Generalitat - ukształtowany historycznie system własnych instytucji polityczno-prawnych Katalonii, na czele z systemem władzy. 
przesłanek” narodu (Szacki, 1997: 16). Wielość i złożoność ujęć pojęcia „narodu” oznacza, że przyznanie danej grupie takiego statusu wydaje się wyłącznie kwestią polityczną. Definicje narodu mają bowiem nierzadko charakter instrumentalny, służąc określonym celom politycznym (Barwiński, 2004: 60). Jest tak również w przypadku Katalończyków, którzy w zależności od perspektywy czy interesu politycznego są lub nie są uznawani za naród.

\section{Specyfika regionalizmu katalońskiego}

Regionalizm kataloński może mieć dwa wymiary: w odniesieniu do samej Katalonii oraz w szerszym rozumieniu - leżącym u podstaw ruchu pankatalońskiego odwołującego się do pojęcia Krajów Katalońskich (kat. Països Catalans) (Szul, 2015: 23). Kraje Katalońskie to obszar, którego mieszkańcy posługują się językiem katalońskim, obejmujący swym zasięgiem części terytoriów czterech państw: w Hiszpanii, oprócz Katalonii, są to Walencja, Baleary i część Aragonii, a ponadto Andora, Francja (region Roussillon) oraz Włochy (miasto Alghero, kat. Alguer, na Sardynii). Wspólne podłoże kulturowe, językowe i historyczne Krajów Katalońskich stanowi punkt odniesienia dla ruchu niepodległościowego, którego część przedstawicieli głosi postulaty separatystyczne właśnie w stosunku do Països Catalans, nie ograniczając swoich dążeń czy aspiracji tylko do samej Katalonii (Rovira Martínez, 2016: 20-21). Jednakże odwoływanie się do koncepcji Krajów Katalońskich wyraźnie ma charakter ideowy i funkcjonuje obecnie w ograniczonym obiegu kulturowym. Wizja Països Catalans, prócz Wspólnoty Autonomicznej Katalonii, nie wydaje się bowiem znamiennym elementem tożsamości mieszkańców ziem, na które owa koncepcja się rozciąga. Koncept ten często bywa tam w ogóle nieznany lub jest wręcz postrzegany negatywnie. Dla katalońskiego ruchu niepodległościowego (a przynajmniej jego części) Kraje Katalońskie stały się natomiast swego rodzaju symbolem dziedzictwa historycznego oraz odrodzenia narodowego i kulturowego Katalonii, co stanowi punkt oparcia tożsamości dla zwolenników niepodległości regionu (Pobóg-Lenartowicz, 2016: 314). 
Zwolennicy niepodległości Katalonii bazują na szerokiej definicji narodu i argumentach obejmujących zarówno czynniki kulturowe i językowe, jak i historyczne, polityczne, ekonomiczne czy społeczne. Dla ruchu niepodległościowego istotne znaczenie ma poczucie odrębności, motywowane i umacniane pamięcią historyczną o dziejach Katalończyków. Oprócz czynnika historycznego ważny jest również aspekt kulturowy i językowy - obrona i promowanie własnej kultury i języka czy możliwość zachowania edukacji w języku katalońskim. Nie mniej istotna dla zwolenników budowania katalońskiej państwowości pozostaje jednak także otwartość na inne grupy etniczne czy kulturowe (co wynika m.in. ze złożoności tożsamości mieszkańców regionu), dlatego też często kładą oni nacisk na elementy związane ze stanem demokracji, a zwłaszcza dobrobytem (Vergés-Gifra, Serrano, Serra, 2019: 69). Dla katalońskiego ruchu separatystycznego czynnik ekonomiczny wydaje się bowiem kluczowy. Poprzez samodzielną politykę finansową rząd kataloński utrzymuje, że mógłby zapewnić stabilniejszy rozwój Autonomii, zwłaszcza w sytuacji, gdy Katalonia, jako jeden z najbogatszych regionów Hiszpanii, zmuszona jest odprowadzać więcej do budżetu centralnego, niż z niego realnie otrzymuje. Ma to swoje konsekwencje społeczne - obecne u części katalońskich separatystów i manifestowane przez nich poczucie dystansu do innych grup etnicznych państwa hiszpańskiego, motywowane wspomnianą wcześniej przewagą ekonomiczną nad pozostałymi wspólnotami autonomicznymi. Oprócz tego dla katalońskiego ruchu niepodległościowego szczególnie ważny jest aspekt polityczny - osiągnięcie suwerenności politycznej umożliwiającej obronę interesów Katalończyków czy to w ramach pogłębienia autonomii, czy w ostateczności secesji i osiągnięcia pełnej niepodległości.

\section{Wyrok Trybunału Konstytucyjnego Hiszpanii z 2010 roku}

Proces związany z wejściem w życie Statutu Autonomii Katalonii z 2006 roku nie był prosty. Jeszcze przed uchwaleniem Statutu jego treść została znacznie okrojona przez hiszpański parlament, jednak ostatecznie Statut został zaaprobowany przez władze Hiszpanii 
i przegłosowany w referendum w Katalonii. W 2010 roku doszło do kolejnego ograniczenia postanowień statutowych, kiedy to w czerwcu Trybunał Konstytucyjny Hiszpanii orzekł, że wybrane artykuły Statutu wymagają zmian, ponieważ są niezgodne z hiszpańską konstytucją (łącznie 14 artykułów), a część artykułów i przepisów jest konstytucyjna tylko pod warunkiem ich właściwej interpretacji (łącznie 23 artykuły i 4 przepisy dodatkowe) (Sentencia 31/2010). Za niezgodne z konstytucją hiszpańską uznano: możliwość ustanawiania własnych podatków na szczeblu lokalnym (art. 218.2) oraz założenie, że finansowy wkład Katalonii do tzw. „funduszu solidarności” powinien być uzależniony od podjęcia podobnego wysiłku fiskalnego przez inne wspólnoty autonomiczne (art. 206.3). Zakwestionowano również status języka katalońskiego jako języka „preferowanego” w administracji i mediach publicznych (art. 6.1). Uznano, że obowiązek posiadania kompetencji w języku katalońskim w Katalonii (art. 6.2) nie może być rozumiany w charakterze prawnie wykonanego obowiązku o uogólnionym charakterze [w porównaniu z obowiązkiem posiadania kompetencji w języku kastylijskim (hiszpańskim) zawartym w hiszpańskiej konstytucji]. Za niezgodne z konstytucją uznano również przyznanie wyłącznego nadzorowania katalońskiej administracji regionalnemu Rzecznikowi Praw Obywatelskich (kat. Síndic de Greuges) (art. 78.1), zarządzanie wymiarem sprawiedliwości regionu przez Radę Sprawiedliwości Katalonii (kat. Consell de Justícia de Catalunya) (art. 97) oraz status przewodniczącego Wyższego Trybunału Sprawiedliwości Katalonii (kat. Tribunal Superior de Justícia de Catalunya) jako przedstawiciela władzy sądowniczej w regionie nominowanym przez hiszpańskiego króla (art. 95.5). Postanowienie Trybunału odnosiło się także do kwestii związanych z określeniem Katalończyków jako narodu. Zamieszczone w preambule Statutu sformułowanie przyjęto jako pojęcie niemające mocy prawnej, stwierdzając także, że jedynym narodem uznanym w sensie prawnokonstytucyjnym jest naród hiszpański. Trybunał Konstytucyjny Hiszpanii odniósł się także do wyrażenia „symboli narodowych Katalonii” (art. 8.1), interpretując je jako „symbole narodowości” i określając symbole narodowe Hiszpanii jako jedyne, które można uznać za „narodowe”. 


\section{Ewolucja katalońskiego ruchu niepodległościowego w drugiej dekadzie XXI wieku}

Zakwestionowanie Statutu przez hiszpańskie władze odegrało kluczową rolę w życiu politycznym i społecznym regionu. Pierwsze lata drugiej dekady XXI wieku można uznać za początek nowego, współczesnego epizodu w historii katalońskiego ruchu niepodległościowego. Wyrok TK wywołał zdecydowaną reakcję katalońskiego społeczeństwa, którego rozczarowanie zaczęło stopniowo przeradzać się w żądania niepodległości regionu (Grass, 2018: 4). Jawną oznaką niezadowolenia dużej części Katalończyków była demonstracja pod hasłem „Jesteśmy narodem. My decydujemy” (kat. Som una nació. Nosaltres decidim), zorganizowana 10 lipca 2010 roku przez organizację Òmnium Cultural, w której wzięło udział ponad milion osób. Ponadto w latach 2009-2011 odbył się cykl niewiążących i nieoficjalnych referendów w sprawie niepodległości w ponad 500 katalońskich gminach (Marcet, 2019: 6), co stanowiło wyraźny sygnał ożywienia nastrojów separatystycznych $w$ regionie.

W 2010 roku fala protestów w Katalonii o charakterze proniepodległościowym zbiegła się w czasie z kampanią wyborczą do Parlamentu Katalonii. Słabości i trudności, z jakimi mierzyła się w tamtym okresie trójstronna koalicja złożona z ERC (kat. Esquerra Republicana de Catalunya), PSC (kat. Partit dels Socialistes de Catalunya) i ICV (kat. Iniciativa per Catalunya Verds), wykorzystała CiU (kat. Convergència i Unió) (Marcet, 2019: 5). Dzięki efektywnie przeprowadzonej kampanii ugrupowanie po wyborach w listopadzie 2010 roku wróciło do władzy, którą utraciło w 2003 roku, i sformowało rząd mniejszościowy wraz z chadecką PPC (kat. Partit Popular de Catalunya).

Mogło się zatem wydawać, że napięcie w katalońskim społeczeństwie po pewnym czasie wygaśnie, jednak nieustające trudności polityczne, gospodarcze i społeczne były impulsem do dalszych wystąpień i protestów. Katalończycy masowo wychodzili na ulice, wyrażając swój sprzeciw wobec hiszpańskich instytucji. Powstały nowe ruchy 
polityczne i obywatelskie, takie jak ruch M-152 czy Katalońskie Zgromadzenie Narodowe (kat. Assemblea Nacional Catalana-ANC). Szczególną datą okazał się 11 września 2012 roku, czyli dzień Diada Nacional de Catalunya - najważniejszego święta narodowego Katalończyków. Doszło wtedy do masowych proniepodległościowych wystąpień, a kataloński rząd wyraźnie wezwano do rozpoczęcia procesu secesji od państwa hiszpańskiego. Ponadto fiaskiem zakończyły się podjęte negocjacje między wywodzącym się z CiU prezydentem Katalonii Arturem Masem a premierem Hiszpanii Marianem Rajoyem w sprawie przyznania większej autonomii fiskalnej dla regionu (tzw. pakiet fiskalny). Wydarzenia te ostatecznie skłoniły przewodniczącego Generalitat do ogłoszenia przedterminowych wyborów jeszcze w tym samym roku. Wykorzystując okazane poparcie społeczeństwa dla niepodległości, Mas ogłosił, że „wybory nie odbędą się, aby pomóc partii $\mathrm{w}$ utrwaleniu się $\mathrm{u}$ władzy. Zostaną przeprowadzone tak, aby cała ludność Katalonii w sposób demokratyczny i pokojowy zadecydowała o swojej przyszłości jako naród" (Grass, 2018: 4).

CiU osiągnęła kolejne zwycięstwo wyborcze, zdobywając 30,7\% głosów poparcia (Generalitat de Catalunya, 2012), co oznaczało zaufanie ruchu niepodległościowego do ugrupowania. Chociaż w swoich programach i deklaracjach politycznych CiU nigdy jednoznacznie nie ubiegała się o niepodległą Katalonię, a politycy formacji weszli w zaciekłą rywalizację o uznanie społeczne z otwarcie niepodległościową ERC, to po wyborach w 2012 roku ERC finalnie podpisała porozumienie o koalicji z CiU, w którym uzgodniono również, że w ciągu dwóch lat zostana przeprowadzone konsultacje lub referendum w sprawie niepodległości Katalonii (Marcet, 2019: 10). W kwietniu 2014 roku hiszpański Kongres odrzucił jednak propozycję zorganizowania referendum. Ostatecznie w listopadzie tego samego roku odbyły się tzw. konsultacje w sprawie politycznej przyszłości Katalonii. W niewiążącym referendum wzięło udział ponad 2,3 miliona obywateli. Spośród nich ponad 1,8 miliona osób odpowiedziało twierdząco na dwa

${ }^{2}$ Ruch M-15 (hiszp. Movimiento 15-M) - fala protestów społecznych w Hiszpanii w latach 2011-2015. 
następujące pytania: „Czy chcesz, aby Katalonia stała się państwem?” oraz „W przypadku odpowiedzi twierdzącej, czy chcesz, aby to państwo stało się niezależne?" (Generalitat de Catalunya, 2014). Jeszcze wcześniej, bo pod koniec stycznia 2013 roku, Parlament Katalonii zatwierdził większością głosów Deklarację suwerenności i prawa do decydowania o ludności Katalonii (kat. Declaració de sobirania i el dret a decidir del poble de Catalunya) (Resolució 5/X, 2013), którą Trybunał Konstytucyjny Hiszpanii uznał za niezgodną z hiszpańską konstytucją.

Szczególną rolę w propagowaniu proniepodległościowych postulatów w tamtym czasie odegrały oddolne stowarzyszenia. Ich działalność przyciągała uwagę mediów i opinii publicznej nie tylko w Hiszpanii, ale także poza nią. Ostateczny cel aktywności obywatelskiej skupiał się wokół wymuszenia na katalońskich partiach politycznych aprobaty dla referendum niepodległościowego oraz zwiększenia poparcia społecznego dla idei separatystycznych (Guinjoan, Rodon, 2016: 41). Działania te przyniosły skutek i liczba obywateli opowiadających się za niezależnością Katalonii znacząco wzrosła, a ponadto w 2015 roku rozpadła się koalicja CiU. CDC (kat. Convergència Democràtica de Catalunya), mając bardziej przychylne stanowisko proniepodległościowe w porównaniu z bardziej umiarkowaną UDC (kat. Unió Democràtica de Catalunya), utworzyła wraz z innymi ugrupowaniami nową formację Junts pel Sí („Razem dla tak” - JxSí) (Marcet, 2019: 16). Skupiając dodatkowo takie stronnictwa, jak ERC (kat. Esquerra Republicana de Catalunya), DC (kat. Demòcrates de Catalunya), MES (kat. Moviment d'Esquerres), RI (kat. Reagrupament), a także ruchy obywatelskie: ANC (kat. Assemblea Nacional Catalana), Òmnium Cultural czy AMI (kat. Associació de Municipis per la Independència), stworzono silną proniepodległościową koalicję, mającą szansę na uzyskanie wysokiego poparcia społecznego. Wynik wyborów do autonomicznego Parlamentu Katalonii z września 2015 roku ukazał aprobatę dla nowej formacji: na 135 miejsc w parlamencie, 62 mandaty (prawie 40\%) zdobyło właśnie JxSí. Osiągnięto także rekordową frekwencję na poziomie 77\% (Generalitat de Catalunya, 2015), co stanowiło kolejną oznakę wzmożonej aktywności 
katalońskiego społeczeństwa, a zwłaszcza jego części opowiadającej się za niepodległością regionu.

Jawnym sygnałem separatystycznych dążeń zwycięskiej formacji było przyjęcie już w listopadzie 2015 roku uchwały „w sprawie rozpoczęcia procesu politycznego w Katalonii w następstwie wyników wyborów" (Resolució 1/XI, 2015). Deklaracja zapowiadała budowę niezależnego państwa, niepodlegającego w żaden sposób hiszpańskiej władzy, co doprowadziło do zakwestionowania jej przez Trybunał Konstytucyjny Hiszpanii. Konflikt na linii Barcelona-Madryt stopniowo narastał, co znalazło odbicie w kolejnych ustawach czy dekretach katalońskiego parlamentu podważanych przez hiszpańskie instytucje. W marcu 2015 roku władze katalońskie oczekiwały aż na 58 wyroków Trybunału (Strubell, 2016: 17). Mimo że większość spraw dotyczyła zagadnień o charakterze gospodarczym lub społecznym, to hiszpańskie władze szczególnie niepokoiły działania związane z procesem niepodległościowym. Owa tendencja była kontynuowana w 2016 roku, kiedy na prezydenta Generalitat został zaprzysiężony Carles Puigdemont, wybrany z ramienia Junts pel Sí polityk o poglądach separatystycznych. Przełomowy miał się jednak okazać rok 2017, na który przewidziano wybory parlamentarne, referendum dotyczące niezależności Katalonii oraz finalnie zakończenie procesu niepodległościowego rozpoczętego w 2015 roku.

\section{Próba utworzenia niepodległego państwa w 2017 roku oraz jej następstwa}

Sam zamiar organizacji referendum stanowił burzliwą kwestię dla katalońskich polityków i opinii publicznej, zwłaszcza że według władz Katalonii wyniki głosowania miały być tym razem wiążące. W autonomicznym parlamencie dochodziło do konfrontacji i ożywionych dyskusji na temat charakteru działań budzących wątpliwości chociażby pod względem konstytucjonalnym. Jednak katalońskie władze mogły liczyć na poparcie społeczne i 6 września, mimo burzliwej i pełnej przerw sesji, większości niepodległościowej udało się uchwalić ustawę o referendum w sprawie samostanowienia (Ley 19/2017), zawieszoną 
następnie przez hiszpański Trybunał Konstytucyjny. Jednocześnie nasiliły się naciski polityczne ze strony władzy centralnej, w tym działania policyjne, mające na celu powstrzymanie referendum (Marcet, 2019: 24). Mimo to 1 października ponad 2 miliony obywateli Katalonii odpowiedziało na pytanie: „Czy chcesz, aby Katalonia stała się niepodległym państwem w formie republiki?" (w językach katalońskim, hiszpańskim i oksytańskim). Opinią publiczną nie tylko w Katalonii i Hiszpanii, ale także w Europie i na świecie wstrząsnęły akcje hiszpańskiej policji, podjęte, aby uniemożliwić obywatelom udział w głosowaniu. W Barcelonie i innych katalońskich miastach doszło do aktów przemocy, w efekcie których udzielono pomocy medycznej kilkuset rannym, a nieproporcjonalnie brutalne działania policji wywołały głębokie oburzenie społeczne. Mimo gwałtownego przebiegu wydarzeń oraz braku zabezpieczenia technicznego referendum katalońskie władze uznały ważność głosowania i 6 października opublikowano oficjalne dane, z których wynika, że w referendum wzięło udział 2286217 mieszkańców Katalonii (frekwencja na poziomie 43,03\%), a $90 \%$ z nich opowiedziało się za niepodległością regionu (Generalitat de Catalunya, 2017a).

Sytuacja ta spowodowała głęboki kryzys konstytucyjny i otwarty polityczny spór między Barceloną a Madrytem. 10 października proniepodległościowa większość parlamentarna podpisała deklarację niepodległości Republiki Katalonii, zawieszoną natychmiast przez Carlesa Puigdemonta w celu przeprowadzenia negocjacji z władzami centralnymi. Ostatecznie deklarację niepodległości 27 października zaakceptował kataloński parlament ( 70 głosów za, 10 przeciw, 2 wstrzymujących się i 53 nieobecnych w zgromadzeniu), a w odpowiedzi hiszpański senat zatwierdził warunki stosowania art. 155 Konstytucji do instytucji Generalitat, aby rozwiązać kataloński rząd i parlament oraz zawiesić funkcjonowanie 140 najwyższych stanowisk administracji regionalnej Katalonii. Część byłych ministrów, w tym wiceprezydent Oriol Junqueras (z ERC), została aresztowana m.in. pod zarzutem wszczęcia buntu, natomiast Puigdemontowi, wraz z czworgiem współpracowników z odwołanego rządu, udało się wyjechać do Belgii. Jednocześnie katalońskim politykom obywatele 
udzielali wsparcia w licznych wystąpieniach i manifestacjach. Aktu niepodległościowego Katalonii nie uznało jednak środowisko międzynarodowe, a Unia Europejska wobec katalońskiego kryzysu okazała bierność (Molenda, 2020: 49-68).

Tymczasem zbliżały się przyspieszone wybory parlamentarne zapowiedziane na 21 grudnia. Koalicja Junts pel Sí podzieliła się na Junts per Catalunya (JxCat), skupiające stronników Puigdemonta i szereg niezależnych polityków, oraz koalicję Esquerra Republicana de Catalunya i Catalunya Sí (ERC-CatSí), koncentrującą zwolenników aresztowanego Junquerasa. Same wybory doprowadziły do dalszego impasu w kwestii niepodległości (Grass, 2018: 6). Mimo że antyniepodległościowa formacja Ciutadans zajęła pierwsze miejsce (25,3\% głosów), to następne w kolejności JxCat $(21,6 \%)$ i ERC-CatSí $(21,4 \%)$ utrzymały większość siły separatystycznej w parlamencie. Sama frekwencja wyniosła aż 79,1\% (Generalitat de Catalunya, 2017b). Jednak większości niepodległościowej utworzenie nowego rządu koalicyjnego zajęło aż pięć miesięcy, podczas których dochodziło do wielu kontrowersji prawnych i politycznych. Jednocześnie Hiszpania próbowała utrudnić działania katalońskim politykom i w efekcie międzynarodowa wiarygodność hiszpańskich instytucji zaczęła być podważana (Marcet, 2019: 31). Ostatecznie udało się jednak utworzyć nowy rząd, a 14 maja 2018 roku na prezydenta Generalitat został wybrany Quim Torra.

Lata 2018 i 2019 upłynęły pod znakiem procesu katalońskich przywódców. Dla ruchu niepodległościowego w Katalonii, ale i części obywateli z nim niezwiązanych, aresztowanie polityków było jawnym nadużyciem władzy. Ważny aspekt sytuacji stanowi fakt, że Carles Puigdemont, Antoni Comín (były minister zdrowia katalońskiego rządu) oraz uwięziony Oriol Junqueras w maju 2019 roku zostali wybrani na posłów IX kadencji Parlamentu Europejskiego. Ostatecznie tylko pierwszych dwóch objęło urząd europarlamentarzysty, natomiast Junqueras został pozbawiony uprawnień mimo korzystnego dla niego wyroku Trybunału Sprawiedliwości Unii Europejskiej (TSUE) (Judgment of the Court in Case C-502/19, 2019). Proces przeciw niepodległościowym politykom zakończył się 14 października 2019 roku, kiedy Sąd Najwyższy Hiszpanii skazał dziewięciu katalońskich przywódców na 
kary od 9 do 13 lat więzienia za bunt i malwersację środków publicznych oraz trzy osoby na 10 miesięcy za nieposłuszeństwo obywatelskie. Najwyższą karę 13 lat pozbawienia wolności otrzymał Junqueras.

Wyrok hiszpańskiego Sądu Najwyższego wywołał ogromne poruszenie w Katalonii. Tak jak dwa lata wcześniej, doszło do masowych protestów i walk z policją. W nocy na ulicach katalońskich miast płonęły barykady, a protestujący domagali się uwolnienia skazanych polityków. Warto pamiętać, że podczas wystąpień postulaty niepodległościowe odeszły na drugi plan, a głównym hasłem stało się „Llibertat presos politics” („Wolność więźniom politycznym”). Kolejny raz doszło także do aktów przemocy ze strony policji, a na skutek wydarzeń kilkaset osób zostało rannych (Little, 2019). Mimo deklaracji gotowości ze strony katalońskich władz nie doszło do oficjalnych rozmów z rządem hiszpańskim, a premier Hiszpanii Pedro Sánchez stanowczo odmawiał dialogu. Ponadto 18 października odbył się strajk generalny, w którym w samej Barcelonie uczestniczyło ponad pół miliona osób, jednak do końca 2019 roku spór na linii Barcelona-Madryt nie został rozwiązany. Nie udało się także osiągnąć całkowitej niezależności regionu - o co postulował kataloński ruch niepodległościowy.

\section{Ruch niepodległościowy w drugiej dekadzie XXI wieku w wy- miarze spolecznym}

Obraz niepodległościowych dążeń w ostatnich latach w Katalonii pokazuje, że współczesna historia regionu stanowi złożony i dynamiczny proces nie tylko w wymiarze politycznym, ale i społecznym. Okoliczności uchwalenia Statutu Autonomii Katalonii z 2006 roku stały się kluczowe dla sprawy katalońskiej, ponieważ nowy dokument w zamierzeniu miał wzmocnić rozwój autonomii regionu. Jednocześnie w sferze publicznej pojawiła się idea ,prawa do decydowania”, która doprowadziła do zwiększonej mobilizacji społecznej, jednak w tamtym momencie postulat ten nie był ściśle związany z programem niepodległościowym, lecz stanowił wyraz potrzeby pełnego rozwinięcia potencjału nowego statutu (Serrano, 2017: 144). Wyrok hiszpańskiego Trybunału zakwestionował katalońskie aspiracje, co okazało się 
punktem przełomowym dla myślenia znacznej części Katalończyków. Odmawiając uznania niektórych zasadniczych części nowego Statutu, Trybunał nie uznał tym samym przyjętego w referendum prawa Katalończyków do samodecydowania.

Reakcja katalońskiego społeczeństwa była natychmiastowa. W oczekiwaniu na niekorzystną decyzję Trybunału w sprawie Statutu różne gminy w całej Katalonii organizowały nieformalne głosowania w sprawie niepodległości Katalonii. Większość obywateli nie postrzegała jeszcze wtedy osiągnięcia niezależności regionu za cel możliwy do osiągnięcia w dającej się przewidzieć przyszłości, jednak stanowisko Trybunału zintensyfikowało rozczarowanie Hiszpanią, wywołując polityczne i psychologiczne pęknięcie w ramach instytucjonalnych (Marcet, 2019: 8) i jednocześnie umacniając nastroje proniepodległościowe. Sprzeciw katalońskiego społeczeństwa wobec niesprawiedliwego traktowania przez hiszpańskie państwo i jego instytucje nałożył się na postulat uznania go za podmiot zdolny do wyrażania własnych opinii (Marcet, 2019: 8). W coraz liczniejszych wystąpieniach i protestach ogólne żądanie ,prawa do decydowania” nabrało szczególnego znaczenia w hasłach popierających niepodległość Katalonii. Stopniowo zaczął się formować znaczący i silny ruch niepodległościowy, który do tamtej pory stanowił mniejszość i nie odgrywał istotnej roli w życiu politycznym oraz społecznym regionu.

Kluczowe wydaje się określenie wartości i czynników, na których mógł oprzeć się odradzający się ruch niepodległościowy. W rozumieniu Oriola Vidala-Aparicia traktowanie procesu niepodległościowego w Katalonii jako bazującego w głównej mierze na tożsamości i kwestiach kulturowych jest błędne (Vidal-Aparicio, 2015). Przywołał on natomiast przykład historii powstania Stanów Zjednoczonych, kiedy zwolennicy niepodległości odwoływali się przede wszystkim do filozofii politycznej Johna Locke'a, a zwłaszcza do idei, że rządy są prawomocne tylko wtedy, jeśli realizują cel, dla którego zostały ustanowione przez rządzonych. Kataloński ruch niepodległościowy w znacznym stopniu identyfikuje się z tą koncepcją. Prawdą jest, że zwolennicy separatyzmu Katalonii odnosili i nadal odnoszą się do historycznej przeszłości regionu, a także języka nacjonalizmu 
(chociażby przez hasło Som una nació. Nosaltres decidim - „Jesteśmy narodem. My decydujemy"), jednak ciężar argumentacji za niepodległością opiera się na kwestiach ekonomicznych i pragmatycznych związanych z ogólnym dobrobytem - nie tylko Katalończyków, ale wszystkich mieszkańców regionu, niezależnie od ich przekonań politycznych. Eduardo Mendoza zwrócił uwagę na to, że kryzys finansowy, który w ostatnich latach szczególnie dotknął państwo hiszpańskie, przekształcił kataloński ruch niepodległościowy w ,idealny grunt, żeby dać ujście niezadowoleniu zwłaszcza młodych ludzi mocno pokrzywdzonych sytuacją w Hiszpanii” (Mendoza, 2017: 87).

Co więcej, życie polityczne w Katalonii zdefiniowały liczne wystąpienia i inicjatywy społeczne. Tego typu zjawiska stanowiły „oddolny" proces, poprzez który społeczeństwo wywierało wpływ na ruch polityczny na rzecz niepodległości (Guinjoan, Rodon, 2016: 40). Ponadto dzięki ugrupowaniom separatystycznym debata o suwerenności stała się słyszalna również na forum katalońskiego parlamentu czy w kampaniach wyborczych, a ważną rolę odgrywały w niej środki masowego przekazu - media i internet. Biorąc pod uwagę fakt, że wśród obecnej populacji Katalonii wysoki odsetek stanowią ludzie będący od niedawna częścią katalońskiego społeczeństwa, kwestia tożsamości dla polityków proniepodległościowych nie była tak ważna jak w przeszłości. Wspólnoty politycznej regionu nie definiowano stricte w kategoriach przynależności narodowej, lecz w odwołaniu do infrastruktury społecznej czy transportowej, podatków i obrony praw obywateli (Vidal-Aparicio, 2015). W efekcie, przy narastającej i zauważalnej presji społeczeństwa, partie separatystyczne ugruntowały swoją pozycję w kolejnych zwycięskich wyborach, co oznacza, że wzrost liczby Katalończyków opowiadających się za niepodległością stał się czynnikiem definiującym kierunek polityki Autonomii.

W 2016 i na początku 2017 roku napięta atmosfera wśród katalońskiego społeczeństwa nieco ostygła, niewątpliwie za sprawą poprawy sytuacji gospodarki katalońskiej i hiszpańskiej (Kraus, Vergés-Gifra, 2017: 19). W związku z tym mogło się wydawać, że ruch niepodległościowy zaczął słabnąć, jednak proseparatystyczne nastawienie społeczeństwa regionu nie wygasło. Kontynuację procesu 
secesji potwierdziła dalsza polityka katalońskiego rządu i parlamentu, a punktem zwrotnym w dążeniach separatystycznych okazało się referendum z października 2017 roku. Jednostronne ogłoszenie secesji było jawnym znakiem ewolucji i odstąpienia od, ,prawa do stanowienia" na rzecz prawa do samostanowienia. Zdecydowany opór hiszpańskich instytucji na katalońską próbę oderwania się od Hiszpanii, choć wzmacniał oburzenie znacznej części Katalończyków, to jednak zniweczył niepodległościowe plany. Madryt nie zamierzał iść na ustępstwa czy nawet podejmować negocjacji ze stroną katalońską. Problemem było również to, że według części zwolenników niepodległości katalońscy politycy nie okazali się wystarczająco silni, aby kontynuować jednostronne dążenie do niezależności zgodnie ze złożonymi obietnicami wyborczymi, co wywołało rozczarowanie. Polityczny spór katalońsko-hiszpański podtrzymał proces i wyrok na separatystycznych przywódców. Jednakże w manifestacjach z października 2019 roku żądanie uwolnienia uwięzionych polityków stało się głównym postulatem, który podzielała także część społeczeństwa nieopowiadająca się za secesją regionu. Dało się zauważyć, że postulat niepodległościowy odszedł wtedy na drugi plan, bo nie był on wówczas priorytetem protestujących.

Złożoność podejścia samych Katalończyków do procesu niepodległościowego została również potwierdzona w badaniach własnych autora. Przeprowadzone w styczniu 2020 roku w Katalonii wywiady ukazały dwa spojrzenia: jedno - bezpośrednie oraz pluralistyczne o zabarwieniu proniepodległościowym, a drugie - pragmatyczne i zachowawcze. Z pierwszego punktu widzenia to obywatele Autonomii powinni mieć decydujący głos w stanowieniu o własnym losie (,lud rządzi, rząd jest posłuszny”), a rozwiązaniem dla sprawy katalońskiej jest przeprowadzenie referendum, którego wyniki powinny być uznane przez Madryt. To spojrzenie wydaje się w pewnym stopniu wpisywać w pogląd Oriola Vidala-Aparicia o argumentacji Locke'a związanej z legitymizacją władzy obecnej w kontekście sprawy katalońskiej. Według tych założeń rządy są prawomocne tylko wtedy, gdy spełniają swoją funkcję społeczną i ochronną - jeżeli tak nie jest, społeczeństwo ma prawo do secesji, bo tylko ono (w tym przypadku lud kataloński) 
ma prawo o sobie decydować. Drugi punkt widzenia skupia się natomiast na potrzebie dialogu i próby negocjacji między Katalonią i Hiszpanią. W tym podejściu demonstracje czy jednostronne referenda niczego nie rozwiązują, tylko nasilają konflikt, dlatego, aby wyjść z kryzysu, potrzebna jest ,demokratyczna dojrzałość”. Rozwiązanie konfliktu może nastąpić tylko poprzez dialog i „zdrowy rozsądek”. Wymaga jednak zawarcia kompromisu przez zwaśnione strony, co może wydawać się trudne do osiągnięcia. Obydwa spojrzenia na sprawę katalońską charakteryzują się jednak zbliżonym stosunkiem do procesu i wyroku dla katalońskich przywódców niepodległościowych; uważa się je za niesprawiedliwe i będące wynikiem zatarcia się polityki i władzy sądowniczej.

\section{Wnioski i podsumowanie}

Podjęte przeze mnie rozważania na temat ruchu niepodległościowego w drugiej dekadzie XXI wieku pozwalają stwierdzić, że proces związany z dążeniem do secesji we Wspólnocie jest złożony. Rozwój autonomiczny Katalonii, będący priorytetem polityki regionu przez wiele lat, został nadszarpnięty orzeczeniem hiszpańskiego Trybunału Konstytucyjnego z 2010 roku. Stało się to przełomem w myśleniu wielu Katalończyków, którym odmówiono prawa do samodecydowania. Jednocześnie Hiszpanię dotknął głęboki kryzys finansowy, a narzucona Katalonii przez rząd centralny polityka oszczędnościowa i cięcia wydatków publicznych wywołały poruszenie społeczno-polityczne. Rozczarowanie państwem hiszpańskim i jego instytucjami stopniowo narastało, a w regionie narodził się silny oddolny ruch obywatelski, który w znacznej części zaczął głosić postulaty separatystyczne. Ta oddolna struktura ostatecznie wywołała reakcję środowiska politycznego. Partie niepodległościowe i ich programy wyborcze miały przyciągnąć do katalońskiego ruchu jak największą liczbę zwolenników. Argumenty za secesją zostały odzwierciedlone w żądaniu ,prawa do decydowania", podparte kwestiami ekonomicznymi i społecznymi. Droga Katalończyków do niepodległości pokazała, a raczej stworzyła, tolerancyjny i postępowy nacjonalizm, w którym każdemu obywatelowi, 
któremu zależało na niezależnej i samodzielnej wspólnocie, otwarto drogę do katalońskiego ruchu separatystycznego. Stopniowe ukierunkowanie na możliwość rozwoju autonomii przerodziło się w czasie kilku lat w realny i silny ruch dążący do uzyskania niepodległości regionu. Wola znaczącej części katalońskiej populacji doprowadziła w końcu do referendum w 2017 roku i ogłoszenia Katalonii niezależnym państwem w wyniku jednostronnej deklaracji, a nie poprzez dwustronne i wynegocjowane porozumienie z Hiszpanią. Obecnie wydaje się, że popularność ruchu niepodległościowego w Katalonii spadła, jednak debata na temat suwerenności nie została zakończona, choćby dlatego, że kwestia niepodległości wciąż jest problematyczna i niejednoznaczna dla samych obywateli Katalonii. Niemniej jednak ruch niepodległościowy wciąż wywiera wpływ na życie polityczne i społeczne w Katalonii oraz ma swoich zagorzałych zwolenników, co ukazały wyniki wyborów do katalońskiego parlamentu z lutego 2021 roku, w których partie niepodległościowe po raz pierwszy w historii zdobyły łącznie ponad połowę głosów (53,55\%, ale z frekwencją wyborczą 51,3\%). Z drugiej strony uwydatniły się znaczne różnice pomiędzy „Zwycięskimi” ugrupowaniami w postrzeganiu drogi do osiągnięcia niepodległości regionu, a jedną z kluczowych spornych kwestii pozostaje to, która instytucja powinna pełnić nadzór nad ustanowieniem niezależnego państwa katalońskiego. Przyszłość pokaże, w którym kierunku owa droga poprowadzi.

\section{Bibliografia}

BARWIŃSKI, M. (2004), „Pojęcie narodu oraz mniejszości narodowej i etnicznej w kontekście geograficznym, politycznym i socjologicznym", Acta Universitatis Lodziensis. Folia Geographica Socio-Oeconomica, 5, Łódź, s. 59-74.

GELLNER, E. (1983), Nations and Nationalism, Cornell University Press, Ithaca.

GENERALITAT DE CATALUNYA (2012), Eleccions al Parlament de Catalunya 2012 - Resultats, [on-line] https://bit.ly/2HbrZMo, 9.05.2021. 
GENERALITAT DE CATALUNYA (2014), Resultats Participa 2014, [on-line] https://bit.ly/3w628Kf, 9.05.2021.

GENERALITAT DE CATALUNYA (2015), Eleccions al Parlament de Catalunya 2015, Departament de Governació i Relacions Institucionals (Secretaria General), [on-line] https://bit.ly/2CfICnD, 9.05.2021.

GENERALITAT DE CATALUNYA (2017a), Referèndum d'autodeterminació de Catalunya. Resultats Definitius, [on-line] https://bit.ly/2Rz1Tp0, 9.05.2021.

GENERALITAT DE CATALUNYA (2017b), Eleccions al Parlament de Catalunya 2017. Resum, [on-line] https://bit.ly/3dbTFv6, 9.05.2021.

GRASS, K. (2018), „The Struggle for a Catalan Republic. Rethinking the Way Forward", Platypus Review, 103, [on-line] https://platypus1917. org/2018/02/03/struggle-catalan-republic-rethinking-way-forward/, 9.05.2021.

GUIBERNAU, M. (2000), „Nationalism and Intellectuals in Nations without States. The Catalan Case", Political Studies, 48(5), s. 989-1005, https:// doi.org/10.1111/1467-9248.00291.

GUINJOAN, M., RODON, T. (2016), „Catalonia at the Crossroads. Analysis of the Increasing Support for Secession" w: Cuadras Morató, X. (red.), Catalonia. A New Independent State in Europe? A Debate on Secession Within the European Union, Routledge, London, https://doi. org/10.4324/9781315740584-2.

HECHTER, M. (2000), Containing Nationalism, Oxford University Press, Oxford, https://doi.org/10.1093/019924751X.001.0001.

JUDGMENT OF THE COURT In Case (Grand Chamber) C-502/19 (2019), [on-line] https://bit.ly/333wFw4, 9.05.2021.

KRAUS, P. A., VERGÉS-GIFRA, J. (red.) (2017), The Catalan Process. Sovereignty, Self-Determination and Democracy in the 21st Century, Generalitat de Catalunya, Institut d'Estudis de l'Autogovern, Barcelona.

LEY 19/2017, de 6 de septiembre, del referèndum de autodeterminación (2017), [on-line] https://bit.ly/38YOhwV, 9.05.2021.

LEY ORGÁNICA 6/2006, de 19 de julio, de reforma del Estatuto de Autonomía de Cataluña (2006), [on-line] https://bit.ly/3nZSea1, 9.05.2021.

LITTLE, O. (2019), 28 Sent to Jail after Week of Disorder in Catalonia, Catalan News, [on-line] https://bit.ly/2RDrxvE, 9.05.2021. 
LLIBERTAT.CAT (2020), L'independentisme català. Un moviment nou, [on-line] https://bit.ly/3gHtIVK, 9.05.2021.

MARCET, J. (2019), Eight Years of Pro-independence Effort in Catalonia. Elections, Actors and the Political Process, Institut de Ciències Polítiques i Socials, Barcelona.

MENDOZA, E. (2017), Co z ta Kataloniq?, tłum. K. Jaszecka (2018), Sonia Draga, Katowice [tytuł oryginalny: ¿Qué está pasando en Cataluña?].

MOLENDA, P. (2020), Unia Europejska wobec dążén niepodległościowych Katalończyków na przykładzie stosunku do referendum z 2017 roku, [on-line] https://bit.ly/3iJcpFI, 9.05.2021.

POBÓG-LENARTOWICZ, M. (2016), „Imperium bez państwa, państwo bez granic - koncepcja Països Catalans we współczesnej myśli społeczno-politycznej Katalonii”, Pogranicze. Polish Borderlands Studies, 4(2), s. 301-319, https://doi.org/10.25167/ppbs411.

RESOLUCIÓ 1/XI del Parlament de Catalunya, sobre l'inici del procés polític a Catalunya com a conseqüència dels resultats electorals del 27 de setembre de 2015 (2015), [on-line] https://bit.ly/3dkEgsw, 9.05.2021. RESOLUCIÓ 5/X del Parlament de Catalunya, per la qual s'aprova la Declaració de sobirania i del dret a decidir del poble de Catalunya (2013), [on-line] https://bit.ly/2NbY4Ug, 9.05.2021.

ROVIRA MARTÍNEZ, M. (2016), „Entre els Països Catalans i la independència de Catalunya”, Eines per a l'esquerra nacional, 26, Barcelona, s. 16-25.

SENTENCIA 31/2010 (Tribunal Constitucional) (2010), [on-line] https://bit. ly/2UILUWA, 9.05.2021.

SERRANO, I. (2017), „Normative Views in Practice. The Political Discourse on Secession in Catalonia 2003-2015" w: Kraus, P. A., Vergés-Gifra, J. (red.), The Catalan Process. Sovereignty, Self-Determination and Democracy in the 21st Century, Generalitat de Catalunya, Institut d'Estudis de l'Autogovern, Barcelona.

SMITH, A. D. (1995), Nations and Nationalism in a Global Era, Polity Press, Cambridge.

STRUBELL, M. (2016), „The Catalan Independence Process and Cold Repression (2003-2016)", Razprave in Gradivo Revija za Narodnostna Vprašanja, 77, s. 5-30. 
SZACKI, J. (1997), „O narodzie i nacjonalizmie”, Znak, 3, Kraków, s. 4-31. SZUL, R. (2015), ,Regionalizm w Hiszpanii”, MAZOWSZE Studia Regionalne, 16, Warszawa, s. 13-51.

TOUBEAU, S. (2020), National Self-determination in Times of Shared Sovereignty. Goals and Principles from Catalonia to Europe in the 21st Century, Fundació Catalunya Europa, Barcelona.

VERGÉS-GIFRA, J. (red.), SERRANO, I., SERRA, M. (2019), Un biaix etnicista en la política catalana? L'efecte desigual del ,procés», Càtedra Ferrater Mora de Pensament Contemporani de la Universitat de Girona. VIDAL-APARICIO, O. (2015), Catalonia and the United States. Two Lockean Revolutions 240 Years Apart, [on-line] https://bit.ly/2FLBbXB, 9.05.2021. 